\title{
Towards corporate professionalization: The case of project management, management consultancy and executive search
}

\author{
Daniel Muzio \\ University of Leeds, UK \\ Damian Hodgson \\ University of Manchester, UK \\ James Faulconbridge \\ Lancaster University, UK \\ Jonathan Beaverstock \\ University of Nottingham, UK \\ Sarah Hall \\ University of Nottingham, UK
}

\section{Introduction}

The knowledge economy has been characterised by the proliferation of new forms of expert labour such as IT (Marks and Scholarios, 2007), advertising (Alvesson, 2004), and as discussed in this paper, project management (Hodgson and Muzio, 2010), management consultancy (Fincham, 2006; Kirkpatrick et al, 2011) and executive search (Faulconbridge et al., 2008). Many of these occupations would lay claim to the mantle of 'professionalism'; interestingly, however, they have adopted strategies, tactics and methods which depart in significant ways from the example of established professions such as law, chartered accounting and medicine. The relevant literature has explained this situation with reference to the peculiarities of an occupation's knowledge-base (Reed, 1996; Fincham, 2006) and to the historical challenges of a context which is increasingly sceptical of professional claims (Hanlon, 1999; Muzio and Ackroyd, 2005). In this context, professionalisation, with its emphasis on monopolistic market closure, restrictive practices and self-regulation is, in some quarters, seen as neither desirable nor achievable; rather new knowledge intensive occupations are expected to succeed through innovation, entrepreneurship and active engagement with the markets. Indeed, the success of these new occupations has been presented as evidence of the crisis of professionalism as an occupational template and its displacement by more entrepreneurial and managerial forms of organization (Brock, et al, 1999; Dent and Whitehead, 2002).

Against this background, this contribution looks at recent attempts at professionalisation in project management, executive search and management consultancy. These three occupations have been chosen because, despite some rather different structures and histories, they do share a number of common characteristics in the way they are conducting their own 
professional projects. Specifically, a series of semi-structured interviews with key individuals in the respective professional associations, the Association for Project Management (APM), the Association of Executive Search Consultants (AESC) and the Institute of Management Consultancies (IMC) ${ }^{1}$, and the consideration of published information reveal that whilst elements of 'traditional' professionalization strategies can be identified within in these fields, professionalization processes are guided by new conceptions of professionalism and supported by some novel strategies and tactics. In this context, this paper seeks to develop and assess the prospects for a new model of professionalisation in knowledge-based occupations. In doing so, it highlights the strategies and tactics recently developed by the APM, the AESC and the IMC as part of intricate attempts to negotiate occupational settlements with other actors and especially with the large professional organizations which inhabit and dominate these fields of practice (see also Abbott, 1988; Burrage et al, 1990). In particular, our analysis illustrates the way these new tactics attempt to overcome the challenges that a more hostile institutional and ideological context poses for professionalization as a mode of work organization. Based on these insights it is suggested that the cases of management consultancy, executive search and project management may indicate the emergence of a new model of professionalization, which, following Kipping et al's original definition (2006 - see also Muzio 2010 on this) we term 'corporate professionalization' and which may be more suitable for the contemporary economic landscape and more acceptable in the current political economy.

This analysis will unfold over three sections. The first section will introduce debates over the prospects of professionalism in late modernity in general and more specifically within management consultancy, executive search and project management as distinctive occupational fields. In particular, we will review prominent academic arguments for an occupations' failure or unwillingness to professionalize. The central section, after a brief discussion of the history, structure and occupational strategies of our selected occupations, will propose and illustrate, drawing on the experiences of our three case studies, a new model of professionalization and contrast its key features with established patterns of professional formation. Finally, the concluding section will interpret these current developments as evidence of an emerging corporate form professionalization, which is increasingly dependent

\footnotetext{
${ }^{1}$ Now the Institute of Business Consulting (IBC), following a merger between the IMC and the Institute of Business Advisors
} 
on the deployment of a market-oriented focus and on the acquiescence and sponsorship of the large organizations that currently dominate the production and delivery of expert services.

\section{Professionalism, Professionalisation and Knowledge Work}

Professionalisation has traditionally been understood as the result of a systematic occupational project (Larson, 1977: xvii) aimed at translating scarce technical resources into an institutionalised system of rewards. Market closure through regulation guarantees sizeable economic advantages as it allows occupations to maintain skill scarcity and, therefore, enhance the value of their own work by limiting the number of individuals allowed to provide a service such as medical or legal advice (Larson, 1977). Furthermore, professional closure provides a convenient market and occupational shelter as it offers the professions, to some extent at least, the ability to reconcile supply and demand patterns in their own markets (Abel, 1988) whilst also presenting a line of defence against programmes of managerial intervention and technological rationalization imposed by employing organizations. In this context, professionalization has historically emerged as an extremely significant occupational strategy (Johnson, 1972; Larson, 1977), providing 'the dominant principle and form of organizing and controlling expert knowledge and skill' in the modern era (Reed, 2007: 3).

Yet such strategies are typically presented as being of limited relevance to knowledge workers such as the three case studies presented here (Kyrö 1995; Kubr 1996; Alvesson and Johansson, 2001; Fincham, 2006; Marks and Scholarios, 2007). A key problem is assumed to lie in the "cognitive resources" available to these new expert occupations; their knowledgebase is regarded as too fuzzy, fragmented, indeterminate, perishable and client/context dependent to be formalised into a coherent body of knowledge and portable set of credentials that can sustain traditional processes of occupational closure (Reed 1996; Fincham 2006; Morris et al, 2006). In the language of Glückler and Armbruster (2003) these new professions are characterised by 'unbounded product standards' with members delivering diverse services using heterogeneous methodologies, thus making it hard to compare the competency of individuals or organizations. Furthermore, with such a broad variety of services, roles, methodologies, types of providers, and workplaces there is little scope to develop the sense of community and shared professional identity (cf. Kyrö 1995) which is necessary to support professionalization. 
However, whilst these explanations provide important insights into the challenges and issues faced by 'new' knowledge-based occupations, they say little with regards to the new strategies of professionalization being adopted by a number of these occupations. First, in the existing literature it is assumed that there are some intrinsic or essential characteristics at the heart of these occupations' knowledge bases that prevent their effective professionalization. This stance treats a formal body of knowledge as an a priori prerequisite for professionalization, and, in doing so, ignores the role that professions and their associations play in formalizing, systematizing and polishing their knowledge base as part of deliberate attempts to facilitate collective mobility (Jeffcutt, 2004). Second, and related to this, such explanations also underplay the potential capacity of professional associations to identify alternative forms of occupational closure that are more suited to the nature of their work and of the economic context in which they operate. The result may be the development of closure regimes which focus less on formal knowledge and more on 'professional' service standards (defined in terms of customer focus and reliability), capabilities (such as real-time problem solving) and industry experience (which allows the application of expertise and solutions developed in previous projects). Consideration of such issues is, then, one of the key contributions of this paper as part of a sustained attempt to make sense of emergent tactics of professionalization in 'new' knowledge occupations.

\section{'New' tactics of professionalization?}

It is not new to suggest that occupational closure and professionalization are not only problematic for aspiring professions such as management consultancy but are more generally 'out of kilter' with hegemonic economic logics of our times (Brint, 1994; Reed, 1996, 2007). Broader changes in the political economy (Hanlon, 1999; Muzio and Ackroyd, 2005) driven by successive neo-liberal and increasingly budget-conscious administrations mean that the professions have, for the last 20 years at least, found themselves on the receiving end of an increasing number of deregulatory attentions and cost-cutting interventions (Abel, 2003; Muzio and Ackroyd, 2005). Whilst there is disagreement over the extent of these challenges and on the possibility of resistance (Ackroyd and Muzio, 2007), this neo-liberal onslaught has certainly shaken if not dismantled the normative, regulatory and institutional scaffolding that supported the system of the professions. In particular, formal knowledge credentials nolonger seem to justify market monopolies and, as a result, forces of de-professionalization have been said to have marked the end of the 'golden age' of the professions (Aronowitz and 
Di Fazio, 1994; Burris, 1993; Reed, 2007). Consequently, as the established professions are under sustained attack, the prospects for the blossoming of new professional projects are assumed to be rather limited, even if some (McKenna, 2006) have recently identified in the systemic shocks brought by Enron a renewed appetite for professional regulation (i.e. Sarbannes-Oxley in the US).

Under these circumstances, professionalization through closure based on formal knowledge credentials has been deemed increasingly implausible and, arguably, unnecessary (Alvesson and Johansson, 2002). As a result, knowledge-based occupations such as management consultancy, executive search and project management have prioritized so-called marketisation strategies (Reed, 1996), which emphasize innovation, entrepreneurship and active engagement with the markets over the established professions' concern with closure. The emphasis is, therefore, on aggressive marketing, "locking into and stimulating the seemingly inexhaustible demand for new specialities" (Fincham 2006: 23). Typical of this are:

- the continuous creation of new managerial fads and fashions (Kieser, 2002) which consultants sell to their clients;

- the process of 'projectification' (Boltanski and Chiapello, 2005) through which project managers have legitimized their role and, greatly expanded the boundaries of their own jurisdiction to colonize new domains;

- The deployment of a range of discursive strategies designed to institutionalize the use of executive search professionals as a form of 'best practice' in the search and selection of top management in exchange listed companies (Jones, 1989; The Daily Telegraph, 2005).

This tactical shift is enacted at the discursive and symbolical level through new rhetorics which celebrate technical expertise and its commercial application over the traditional professional claims to public service and the social trusteeship of key competences (Brint, 1994). This shift in the focus of knowledge claims to emphasise the ability to add (commercial) value, we claim, exercises a key if somewhat underestimated role in contemporary professionalization projects as illustrated by the tactics of our three case study occupations.

Our second contention is that whilst much of the debate has focused on knowledge and knowledge claims (Fincham, 2006; Reed, 1996), it increasingly seems that industry and 
workplace structures should also been recognised as relevant factors within professionalization projects. For example, project managers are largely employed within large organizations such as Rolls-Royce, BP or BAe Systems, with a relatively small minority working within corporations as internal consultants, as independents or in relatively small consultancy firms (Morris, 1997). As examples of Reed's (1996) organizational professions, project managers are, therefore, subject to corporate priorities, strategies and structures which in turn they help to reproduce and legitimize. Whilst some groups (e.g. HR managers) have managed to develop professionalization projects in a context where practitioners are dominantly found in large employing organizations, such contexts are not particularly fertile ground for traditional professional projects based on occupational closure and self-regulation.

In contrast to project management, the bulk of management consultants are employed by autonomous professional organizations (Larson, 1977), with a minority working within corporations as internal consultants. However, what may be important here are the peculiar foundational conditions of this industry which was dominated from its inception by relatively large and often global organizations (Gross and Kieser, 2006; Kipping and Kirkpatrick, 2007) which were reluctant to cede control over their labour markets and knowledge bases to an independent professional association. Thus, the political conflict between organizations intent on developing their own brand versions of professionalism (McKenna, 2006) and associations pursuing more traditional professionalization projects may be an important if under-explored theme in the peculiar development of this occupational field. A similar story can be told in relation to executive search which is also dominated by large U.S. and European organizations, complemented by a raft of smaller 'boutique' firms in very niche markets. As a result, as in the case of consultancy, attempts to gain recognition as a profession are bound by the way in which the largest firms define 'professionalism' and professionalization tactics. Thus, professional associations linked to knowledge-based occupations, such as the AESC, IMC and APM, have had to operate in a context in which the firm is a key interlocutor and reference point for any potential professionalization project. This situation is markedly different to the context in which professions such as law and medicine emerged but has not been fully factored into discussions of professionalization in 'new' knowledge-based occupations. 
Below, we, therefore, consider the implications of changing versions of professionalism (i.e., the rise of a market-orientated form of professionalism) and the suggestion that professionalisation, as an occupational strategy, operates in and through firms as well as professional associations to develop a subtly different argument about the prospects and patterns of professionalization in 'new' knowledge-based occupations.

\section{Our three occupations}

\section{Project Management}

While 'project manager' as a job title can be traced back to the early $20^{\text {th }}$ century, discussion about the occupation and its proprietary field of knowledge emerged in the second half of the

$20^{\text {th }}$ century, particularly in relation to large-scale projects in civil engineering, aerospace and defence (Morris, 1997). In recent years, project management methodologies and techniques developed in the field of engineering have been adopted in a wide range of sectors and organisations from Information Systems/Information Technology to new media and international development and consulting, as well as in the Public Sector through the increased reliance on fixed-term public-private partnerships and targeted funding. The shift from a domain of technical expertise to an occupation with aspirations of professional status has, thus, taken place gradually over the last 40 years in line with the growing role of project management in different parts of the economy. This process has, most recently, been driven by the activities of various professional associations.

Globally, project management as a field is represented by several national associations, which vary widely in size, influence and respectability, most of which are themselves members of a global umbrella body, the International Project Management Association (IPMA). The most substantial association, the US-based Project Management Institute (PMI) with some 290,000 members, claims to be the largest professional association in the world (PMI, 2009). Project management in the UK is dominated by the Association for Project Management (APM) who, with around 17,500 individual members and 500 corporate members, is the largest single association within the IPMA. Although the APM was established in the early 1970s, membership only grew to significant levels in the early 1990s.

The rapid recent growth in membership of the professional associations can be traced back to their creation of 'body of knowledge' documents in the late 1980s and early 1990s, designed 
to structure the accreditation of individual practitioners. Since then, the IPMA, APM and PMI have all extended their structure of qualifications to build a career ladder for their members. In particular, the APM which in recent years has undergone rebranding and modernisation, has rapidly expanded the number of corporate members, including several arms of local and national government. This corporate and state patronage has encouraged the association to pursue a Royal Charter, a process initiated in late 2008.

\section{Management Consultancy}

Management consultancy as an occupational field is fragmented along multiple fault-lines. Operators range from sole practices and small partnerships to large multinational organizations, operating in dozens of jurisdictions and employing thousands of consultants (Fincham, 2006; Kipping et al, 2006; McKenna, 2006). Furthermore, the occupation is divided in a plethora of specialisms as consultants offer an increasing range of sophisticated solutions and industry-focused services. The industry first developed its own professional and trade associations in the 1950s, largely in an attempt to pre-empt external intervention. Indeed, institutions such as the Management Consultancy Association (MCA) and IMC assumed from an early stage some of the functions and roles, not to mention the external appearance, associated with professional projects such as the certification of skills and competences, the provision of best practices and deontological guidelines, and of course the lobbying of government and business. However, it must be noted that membership has never been mandatory nor, in the case of the IMC, particularly dense. The IMC, as is the case of the APM, is also part of a global umbrella association the International Council of Management Consultancy Institutes (ICMCI), which brings together the various national associations and has developed common competence based qualifications, in the form of the Certified Management Consultant (CMC) award.

In terms of size, the IMC historically reached a plateau of around 3000-3500 members; today its successor the Institute of Business Consulting (IBC) (formed in 2007 by a merger of the IMC with the Institute of Business Advisors) has approximately 7000 members. Clearly, membership numbers received an immediate boost from the merger, but it still represents a small proportion of the total number of practicing consultants ${ }^{2}$. To address this situation, the

\footnotetext{
${ }^{2}$ Whilst there are no certain data with regards to the total population of consultants, this figure is likely to be under $10 \%$.
} 
Institute of Management Consultancy has experimented, with varying degrees of success, with a range of new professionalisation tactics, which will be reviewed below.

\section{Executive Search}

Executive search firms specialise in filling corporate vacancies, by headhunting an individual from a rival organization. It was between 1950 and 1970 that executive search firms as independent entities proliferated after consultants took the service out of management consultancy firms and made it into a standalone business (Beaverstock et al., 2006). Significantly, as with management consultancy, the industry quickly became heterogeneous in nature. Most fundamentally, a split quickly emerged between 'retained' and 'contingent' executive search firms, the former specialising in elite, 'top- and middle-tier' labour recruitment with guaranteed payment by client's for successful placements (usually defined in the UK as positions with starting salaries of above $£ 100,000$ ) and the later offering fullservice across all parts of the organizational hierarchy, including traditional recruitment services, with more precarious client-fee structures (Faulconbridge et al., 2008; Jenn, 2005). The global search industry is dominated by retained firms and it is this section of the executive search occupation that has engaged in attempts at professionalization.

The AESC, established in 1959, is the industry association representing retained executive search organizations. Membership is at the firm-level (not individual practitioner level) with around 257 firms, employing 6000 practitioners, being members of the AESC worldwide ${ }^{3}$. Unlike the examples of project management and management consultancy, the AESC is itself a global organization with no national associations existing. From the offset, then, executive search has been represented by an association with an international remit and strategy rather than national associations allied under a global umbrella organization. The 257 firms that are members of the AESC range from small boutiques employing tens of practitioners and providing search and selection services for one industry only (e.g. investment banking) through to large fully integrated global firms employing thousands of practitioners in tens of offices that offer full service search and selection that cuts across industries as diverse as finance and higher education, or mechanical engineering and public sector management.

\footnotetext{
${ }^{3}$ Data on membership numbers taken from AESC website (http://www.aesc.org/article/memberlistsz/) on $23^{\text {rd }}$ June 2009
} 


\section{Introducing Corporate Professionalism}

This next section attempts to frame our three case studies in a template of corporate professionalism (Kipping et al, 2006; Muzio et al, 2010) and contrasts this with more established forms of professionalization to tease out relevant differences. It is important to stress how this represents an ideal-type and therefore includes an inevitable element of abstraction and generalization. In particular, owning to their different structures, functions and histories, our occupations present some important individual variations, yet they also display some common characteristics and approaches to professionalization which act as the key components of our model of corporation professionalization.

\section{Knowledge claims - closure}

Closure, the ability to distinguish members from non-members, has historically been at the heart of professionalization projects. This has usually been established on the basis of formal credentials which certified the mastery of an official body of knowledge. Such attempts can be discerned with varying degrees of success in all of our three case study occupations, yet, this is an increasingly difficult strategy in a context characterised by more fluid, indeterminate and relational forms of knowledge (Fincham et al., 2007). Accordingly, project management, management consultancy and executive search have also been developing alternative types of credentials which emphasise competences, transferrable skills, and industry knowledge and experience.

In the case of management consultancy the IMC struggled with the issue of closure and professional qualifications for the majority of its early history. This challenge led to the development of the CMC award. This assesses competency in key management consultancy processes against the Institute's Competence Framework which specifies the standards and capabilities expected from consultants regardless of their area of technical specialization. There is, therefore, a clear attempt to specify common principles, abilities and real life competences (negotiation and communication, project management, expectation management, risk management, etc) that transcend the narrow boundaries of individual practice areas (for example, strategy, BPR, etc) and are common to all types of management consultancy. Here, the emphasis is not so much on the possession of specific forms of knowledge but on the ability to put this into practice (i.e., skills) in a competent, client focused and ethical manner. This requires new assessment methods involving extended 
interviews, client references, presentations, and the critical analysis of the candidates' project portfolio. Yet, in parallel with the investment in new forms of competence-based closure which remain the highest accolade in this area, today the IBC has also been pursuing a more traditional path centred around the development of an official body of knowledge (the MCBOK) and formal qualifications such as the Certificate and the Diploma in Management Consultancy.

Within project management, conversely, the APM has had much more success in developing a credible and authoritative body of knowledge, providing the basis for the introduction of a professional examination in 1996. However, in line with the other professional associations discussed, the APM has recently developed a hierarchy of accreditation to replace the single point of entry into the association: the APM Professional (APMP) - a stand-alone test of a candidate's mastery of the APM Body of Knowledge. This has since been replaced by a 4-tier 'ladder' of qualifications (see http://www.apm.org.uk/qualifications.asp for full details). The rationale behind this 'ladder' reflects current concerns with building a structure for Continuing Professional Development and valuing practical competence over abstract knowledge. Hence the lower levels of accreditation, in particular the APM Introductory Certificate in Project Management and the APM Professional continue to rely on traditional assessments of knowledge (i.e. multi-choice exams and essays, respectively) testing the ability to recall and apply an abstract 'body of knowledge', its principles, techniques and terminology. However, the two higher levels of qualification, the APM Practitioner Qualification and the APM Certificated Project Manager measure competences as practiced rather than accumulated knowledge and the mastery of techniques. For these higher levels of accreditation, competences, as in the case of consultancy, are evaluated through selfassessment, evaluation of $\mathrm{CVs}$, references, a project report, assessment centres and interviews. Hence, as one progresses through the hierarchy of qualifications there is a shift from input- to output-based measures, and also a recognition of the diversity of contexts in which project management is practiced.

Reflecting the approaches taken in management consultancy and project management, the AESC has, at one level, developed a strategy that attempts to mimic the closure strategy associated with the formal knowledge base of professions such as law and medicine. The AESC Certified Researcher/Associate Program is designed to set objective standards, based upon a defined body of formal knowledge, which can be used to ensure all researchers and 
associates meet a minimum level of professional competence. However, the program does not set closure conditions that completely preclude entry to the profession to those without the qualification. The programme is optional and the majority of those who would qualify for certified status have not enrolled on the training program. Moreover, the programme assesses knowledge gained as part of direct experience of being a researcher or associate practitioner and there are no mandatory prerequisite qualifications associated with becoming a researcher or associate practitioner, unlike for example in the case of law where individuals must hold a law degree or equivalent qualification before becoming a trainee. In addition, and further at odds with systems in professions such as law, there are no qualification requirements for consultants. In this role 'industry experience', pertinent to the particular sector a consultant specialises in (e.g. higher education; financial services) is considered of primary importance but is recognised as hard to formally assess. This creates a paradoxical situation in which junior members of the profession can be formally 'tested' and registered but more senior members cannot.

Thus clearly our occupations indicate how new approaches to closure are emerging despite attempts to mimic the knowledge-base approach associated with traditional professions such as law and medicine. The associations representing project management, management consultancy and executive search all in one way or another begun by attempting to identify and assess a coherent body of knowledge that practitioners should possess but, over time, have reoriented, at least partially, their focus towards competences, transferable skills and industry experience, which of course, in turn, require new assessment procedures, often associated with skills acquired 'on the job'.

\section{Membership structure}

Changes in closure regimes in all of our three case studies have resulted in significant adjustments to existing membership structures which include the development of a multilevel entry system based on different grades and levels of affiliation. This recognizes the realities of these occupations in which practitioners join with different degrees of knowledge (often including previous professional qualifications), experience and expertise and then follow multiple career trajectories often moving between roles, sectors and specialisms. However, in this area the most significant development has been the introduction of 
organizational membership schemes through which firms as well as or instead of individuals are able to join an institute as corporate members. This is a common development to all three of our occupations and indicates a departure from the established forms of professionalization which were traditionally limited to the accreditation, representation and regulation of individual members.

Currently the IBC, in addition to its individual membership, has over 150 corporate members on their books, some of which like PA Consulting and KPMG are very large indeed, and it reserves one out of 12 places on its council for a representative of such members (whilst the current chair of the IBC Alan Downey is a partner at KPMG), thus providing these organization, besides with a range of other membership benefits, with the opportunity of influencing the institute's strategic development. Membership comes with the obligation to abide by the institute's ethical and deontological code, to promote IBC membership amongst their employees and to encourage their staff to undergo the CMC process. Indeed, these firms can be accredited to issue the CMC award internally. This momentous development has been symbolically enacted by a two changes of name, first from the Institute of Management Consultants to the Institute of Management Consultancies and, second following its merger with the IBA, to the Institute of Business Consulting (IBC); this re-branding capturing the new priority of engaging with corporate concerns.

Similarly, within project management, the recent actions of the APM have also focused on the need to engage and enrol as corporate members those major corporations who are significantly involved with project management, either as direct employers of project managers or as clients of project management services. APM corporate membership has increased rapidly in the last 5 years (from around 150 to 500 members) and now includes firms such as O2, Fujitsu, KPMG, HBOS and Prudential Insurance alongside major corporations from the traditional project-dominated industries (Rolls-Royce, Balfour Beatty, General Electric, etc). Despite the relative success to date, recruiting new corporate members of a significant size remains challenging; difficulties here reflect the rather attenuated influence of corporate members on APM policy. Unlike in management consultancy, corporate members here do not have a direct say in any votes or issues that are put forward, although there is a forum for corporate representatives to update corporate members on APM strategy and policy and for corporate members to voice their opinions on these. This amicable but slightly distant relationship is reflected in APM's policy to only accredit individual 
members, not corporations, and, unlike consultancy and executive search (see below), not to allow corporations to certify their employees 'en masse'. One area where the APM has had particular success is with regards to the public sector: UK government departments, local authorities and other institutions have displayed an increasing willingness to engage with the APM, taking a lead from the Office of Government Commerce's (OGC) strong support of the association. Across all of these corporate members, however, there appears to be little appetite for greater regulation and participation in the institute's life; the relationship is primarily based upon the provision of commercial services by the APM in return for an annual fee.

Finally, professionalization in executive search has also become focussed on firm-level entity regulation with the AESC being an association of firms from the start and only recently adding individual members. This makes the case of executive search different to management consultancy and project management where corporate membership developed only after initial attempts at individual level membership strategies. Firms that become members of the AESC have to accept the association's 'code of ethics' and 'professional practice guidelines' which, in many ways, define the fundamental knowledge-base of executive search professionals. All practitioners employed by firms are expected to "perform all search consulting assignments competently, and with an appropriate degree of knowledge, thoroughness and urgency" so as to ensure accuracy, avoid conflicts of interest and ensure $\begin{array}{lllll}\text { clients best interests are } & \text { (see }\end{array}$ https://members.aesc.org/eweb/DynamicPage.aspx? webcode=CodeofEthics). The importance of practitioners employed by firms possessing the appropriate knowledge is also inscribed in the 'bills of rights' which states what clients and headhunted candidates can expect in terms of service standards. In effect, then, firm-level entity regulation by the AESC leads to individual practitioner-level regulation but employing firms play the lead role in training, monitoring and disciplining the individual practitioner.

The strength of the AESC and its entity regulation is also undermined by the fact that, like in consultancy, corporate membership is not wholeheartedly embraced with many firms not being registered with the association and one of the iconic firms associated with the development of executive search, Egon Zehnder, not being a member at all. In addition, the 
fact that regulation is relatively 'light touch' and the AESC can only recommend that the entities they regulation - i.e. the firms - punish offenders - ironically usually defined as individuals not firms - who break rules in the client's or candidate's bill of rights further raises questions about the effectiveness of the regime.

In all cases, corporate memberships schemes reflect, then, a mix of realism and opportunism, as they are born from the realization that large firms are increasingly the primary actors and locus of professionalization in contemporary expert work. Whilst the support of large organizational members becomes essential to professionalization in these areas, corporate membership also offers a convenient opportunity to expand the institutes' numbers by reaching out to the individual practitioners working in these firms. It does, however, lead to a different type of professionalization to that associated with accountancy, medicine and law, with individuals increasingly being regulated by employing organizations and only indirectly by professional associations.

\section{Legitimization claims}

The three occupations under analysis tend to promote the merits of professional membership on the basis of the commercial benefits that this delivers to clients. Thus, the strategy is to persuade large corporations and key government departments of the value of professional affiliation. This is therefore rather different from the statutory route pursued by traditional professions, which sought to strike 'regulative bargains' (Cooper et al, 1988) with the state with regards to public safeguard services. In effect, the approach of our three case studies is to use professional associations as a way of promoting and proving the market worth and value-added delivered by professional service providers.

Professionalism in executive search is, for instance, defined in terms of the individually tailored services and the commercial benefits which can be secured by tapping into the (somewhat ill-defined) expertise of executive search practitioners. In this context, the UK government commissioned 'Higgs Report', which argued that in the interest of shareholder rights, all non-executive directors should be appointed by headhunters, is often used as a resource to legitimize such claims and backup the arguments made about the indispensible nature of executive search professionals. Similarly, in management consultancy emphasis is placed on the value adding potential of consultants, who 'can provide a powerful business benefit and improve their clients' performance' (IBC, 2009). Finally in project management 
such commercialism emerges from the change in the PMI's tagline, which was changed in 2004 from 'Building Professionalism in Project Management' to 'Making Project Management Indispensable for Business Results'.

These claims also often emphasise the importance of proprietary technologies, methodologies and knowledge bases which can act as important sources of competitive advantage and help to legitimize the role of the profession. In the case of executive search, particular importance is attached to proprietary databases and search methodologies whilst in both management consultancy and project management legitimacy is often sought from specific models, techniques and frameworks such as Six Sigma, McKinsey's 7-S Framework or the Boston Consulting Group's Matrix which are used to signify the rigour, scientific character and commercial value of individuals' and firms' expertise. Another aspect of this new emphasis on commercial value-added is the tendency, common to our three case studies, to seek more sustained forms of engagement with clients and end users. The IBC, for instance, works closely with the Consultancy Purchasing Steering Group, a representative body of purchasers of consultancy advice, to develop guidelines and best-practices on how to procure, manage and use consultancy services whilst in project management a similar function is performed by the Major Projects Association (MPA) which operates as a knowledge-sharing forum bringing together many large organisations reliant upon projects. Whilst, the AESC uses its 'clients' and 'candidates' bills of rights to emphasise what the association can do for end-users - in terms of setting and ensuring service quality standards as well as executive search consultants themselves.

Hence legitimization for our three case studies is associated with commercial claims centred around notions of value added alongside any residual claim about public interest and social trusteeship which are traditionally associated with professions such as accounting, medicine and law (Brint, 1994). This is significant difference that further indicates the importance of considering changes occurring in approaches to professionalization (see also Evetts, 2003).

\section{Jurisdictions}


Professions have historically had a distinct national focus, with their jurisdictions generally coinciding with national boundaries. However, our three case study occupations, in different ways, display a distinct international dimension and vocation. At its simplest level, this is realized through membership of a global umbrella body, such as the International Project Management Association (IPMA) or the ICMCI, which coordinate international initiatives such as the development of international qualifications, codes of practice and competence frameworks. A good example here is the CMC qualification (and the common competency framework, body of knowledge and international code of conduct which support this) which has been developed by the ICMCI, to act as a global benchmark for individual management consultants. Whilst acting as useful coordination mechanism, such umbrella associations can also implicitly encourage cross-border professional mobility, by enabling individual members to operate outside their own nationally-bound jurisdictions. Significant in this regard is the fact that, already, $50 \%$ of APM members have an international component to their work, and some $6 \%$ are permanently based overseas (APM, 2008). Another aspect of internationalization is the tendency of professional associations to operate internationally and to enlist members outside of their national boundaries often in competition with local incumbents. A good example here is the US-based Project Management Institute (PMI); with over 270,000 members (including 3000 in the UK), PMI is currently the world's largest association in the project management field. PMI, which is not, however, a member of IPMA, has an aggressive globalisation strategy and has established substantial chapters in over 60 countries, although around $70 \%$ of its members still work in the US and Canada. In its search for international members, PMI represents a real rival to the APM within the field of project management in the UK. Thus, as large corporations and their professional advisors internationalize, professional associations appear, then, to be following suit.

The case of the AESC and its field of practice which emerged as transnational from the start is perhaps the clearest example of an international professionalization project. Originally founded in 1959 in New York City, and now also operating out of a Brussels office, the body represents the work of retained executive search firms and their researchers and consultants in 70 countries. ${ }^{4}$ This raises a number of interesting dilemmas if the AESC is to become part of a more formal professionalization project. At its simplest, the AESC has no single national

\footnotetext{
${ }^{4}$ Based on data available at https://members.aesc.org/eweb/DynamicPage.aspx?WebCode=FAQs [accessed 20/12/2009].
} 
government to lobby for professional status. Transnational organizations such as the World Trade Organization are unable to enforce closure in the way that it is usually conceptualised in debates about the professions and, therefore, the AESC faces something of a dilemma. In addition, the fundamental knowledge base, competences and standards set out in the AESC Code of Ethics, in its Professional Practice Guidelines and in the Client's Bill of Rights tend to operate within an Anglo-American understanding of professionalism. This is understandable in that 55 percent of AESC member firms are in the UK or USA. ${ }^{5}$ But it does limit the effectiveness of the strategies designed to legitimize the role of executive search in other countries and particularly in countries in which the role of executive search is not institutionalised and needs a different type of promotion and support compared to the USA and UK (see Beaverstock et al., in press).

The jurisdictional boundaries of our three case studies and their professional associations are, then, markedly different to those of traditional professions such as accountancy, medicine and law in which national domains dominate. This creates new opportunities and challenges and shapes the strategies of professionalization in ways not experienced in other professions. In particular, as predicted by Julia Evetts (1995: 772) the case of these new professions indicates how professional associations are pursuing their traditional objectives and performing their traditional functions (such as lobbying, certification and regulation) but this is increasingly occurring 'within transnational markets and international divisions of labour'.

\section{Synthesis and Analysis}

The three occupations under analysis, whilst having their own peculiarities and trajectories of professionalization, all display some common features pointing to the development of new patterns of professionalization. These features, and their differences when compared to 'traditional' models of professionalization are summarised in Table 1. Crucially, this includes in all three cases an increasing focus on the large organizations which as clients and especially as employers dominate these fields of activity. In this context, the introduction of corporate membership schemes and other forms of organizational engagement is particularly interesting. This development breaks with past tradition as professions have historically attempted to admit, regulate and discipline individual practitioners. There is, then, a realization that in management consultancy, project management and executive search

\footnotetext{
${ }^{5}$ Calculated from Data on membership numbers taken from AESC website (http://www.aesc.org/article/memberlistsz/) [accessed on 20/06/2009]
} 
processes of professionalization are intrinsically connected to the support of large organizations which, after all, employ the great majority of professionals in these domains. Reinforcing this idea, Enron, and other cases of professional malpractice, suggest how increasingly professional misbehaviour can be located at the organizational and systemic as well as at the individual level.

Table 1. Key characteristics of 'corporate professionalization' compared to more 'traditional' models

\begin{tabular}{|c|c|c|}
\hline & $\begin{array}{c}\text { OLD } \\
\text { “Collegial } \\
\text { Professionalization" }\end{array}$ & $\begin{array}{c}\text { NEW } \\
\text { “Corporate Professionalization" }\end{array}$ \\
\hline $\begin{array}{l}\text { Knowledge } \\
\text { Base }\end{array}$ & $\begin{array}{l}\text { Reliance on an abstract body } \\
\text { of knowledge }\end{array}$ & $\begin{array}{l}\text { Co-production of knowledge with industry, } \\
\text { situated knowledge, focus on competences. }\end{array}$ \\
\hline Market & $\begin{array}{l}\text { Statutory Closure via Royal } \\
\text { Charter }\end{array}$ & $\begin{array}{l}\text { Market Closure via corporate practices } \\
\text { (tendering and procurement processes) }\end{array}$ \\
\hline Legitimacy & Legitimised by public benefit & Legitimised by market value \\
\hline $\begin{array}{l}\text { Composition of } \\
\text { Association }\end{array}$ & \begin{tabular}{|l} 
Individual membership \\
Single-tier $\quad$ membership \\
structure
\end{tabular} & $\begin{array}{l}\text { Individual and organisational membership- } \\
\text { Multi-level membership structure }\end{array}$ \\
\hline $\begin{array}{ll}\text { Relation } \\
\text { State }\end{array}$ & Licensed/regulated by state & $\begin{array}{l}\text { Not licensed/regulated, state acts as } \\
\text { (significant) stakeholder/consumer of services }\end{array}$ \\
\hline $\begin{array}{l}\text { Relation with } \\
\text { clients and } \\
\text { employers }\end{array}$ & Arms length & Close engagement \\
\hline Jurisdictions & National & International \\
\hline
\end{tabular}

In this context, any successful professionalization project cannot dispense with the active participation, involvement and also regulation of those large employing organizations which have been so influential in shaping their respective fields of practice. The operation of corporate schemes and the development of forms of entity regulation (e.g. the regulation of firms by the AESC), the introduction of consultation mechanisms with employing and client organizations such as the consultancy purchasing group and the major projects association, 
and the move by the IBC to transfer professional accreditation powers to its corporate members are all significant example of these tendencies. Thus, professionalization in the three occupations under review assumes a distinctive corporate flavour as it increasingly recognises the roles of corporations, which had previously been largely absent from the relevant literature (Burrage et al, 1990), as key sites and vehicles for professionalization projects (Suddaby, Greenwood and Cooper, 2007). In particular, professionalization here becomes bound to and furthered through organizational strategies, tactics, systems and methods as well as through the initiatives and involvement of large corporations. Our case studies, therefore, to use Julia Evett's (2003) terminology, increasingly represent examples of professionalization from 'above' rather than 'within', as this process is largely controlled by the employers of professionals.

This role for large organizations in professionalization strategies is also intimately related to the other trends identified through the analysis of our three case studies. These 'new' professions increasingly operate within a commercialised understanding of professionalism (Hanlon, 1998), which downgrades notions of public service and the social trusteeship of socially relevant skills (Brint, 1994) and celebrates the ability to provide business orientated expert services which add value to clients. Accordingly, the reference point here is no longer an increasingly neo-liberal and budget-conscious state (except in its increasingly relevant capacity as a large consumer of expert services) who is sceptical of professional claims and practices, but the market, with the building of market consensus rather than the achievement of statutory recognition as the key strategy for professionalization. In other words, these associations set out to build a critical mass of consensus around their project and activities by persuading a sufficiently large number of employing organizations and consumers of the commercial merits and safeguards associated with professional membership, accreditation and regulation. The idea being that once a sufficiently large share of the market has been won over and professional qualifications become embedded in corporate tendering processes, professional affiliation would be routinely expected and indeed requested by both clients and employers in their procurement and recruitment strategies; thus, de facto, delivering a market form of occupational closure. In this context, the relationships with institutions such as the Office of Government Commerce, the Chartered Institute of Purchasing and Supply or the (now defunct) Department for Business, Enterprise and Regulatory Reform, which commissioned the UK's Higgs Report, acquire a particularly strategic significance as these 
institutions through their procurement guidelines and best-practices can influence market behaviour. In particular, the support of these institutions can act as a significant seal of approval rising the legitimacy, profile and value of professional membership in these specific markets. Similarly professional membership is presented as a commercial proposition and often marketed in terms of its benefits and value-added, especially in situations such as project management where multiple associations compete over potential members.

Finally, the increasing move towards global associations is a reflection of the activities of major employing organizations and the evolving market for professional services. The now well-documented globalization of a range of professional service providers (Beaverstock et al., 2000; Faulconbridge, 2008) and the cross-border mobility of professionals has led to professional associations responding by globalizing their activities or in the case of the AESC being born global. This marks-out the activities of such associations as distinctly different to their counterparts in architecture, medicine or law which historically have held national remits.

Of course, it is important to recognize how this emergence of what we are terming 'corporate professionalization' in which employing organizations are major influences on professional projects is a process in which old and new coexist and co-penetrate each other as some old strategies (development of formal bodies of knowledge and official qualifications) and objectives (chartered status) associated with historical patterns of professionalization, continue to have a hold on these associations and on some of their members. At the same time it is somewhat simplistic to suggest that 'traditional' professions such as accountancy, medicine and law are homogeneous and have coherent and static professionalization strategies (Malhotra and Morris, 2009) that have not be affected by the increasing influence of the employing professional organization (Faulconbridge and Muzio, 2008; Suddaby et al, 2007). Indeed, many of the trends identified and analysed here are increasingly relevant, although in a less pronounced fashion, to established professional projects. Ultimately, the exact balance between old and new will vary in each occupational and national context and will change over time. In particular, the closer an occupation is to the possibility of developing a formal knowledge base grounded in generalisable and codifiable principles the stronger will be the incentive to tie membership to the mastery of such knowledge and to 
develop traditional examinations to accredit individual members. This tendency is most pronounced in project management in which, notwithstanding the development of competency based qualifications for the most senior positions, the PMBOK is the basis for membership and practice. At the other extreme lies executive search in which there is no easy substitute for industry experience and social capital, with management consultancy occupying a somewhat intermediate position and offering competency based qualifications (CMC) besides more traditional attempts to develop a formal knowledge base. Similarly, despite a new emphasis in professional rhetorics on competing by adding value, engaging with clients and developing commercially attractive propositions, the aspiration for a royal charter, that traditional accolade of state sanction, still lingers in the background of these projects. Hence, we recognise the always contingent nature of any model and suggest here that corporate professionalization is an important trajectory of change with a number of generalisable principles that operate in occupation, place and time contingent fashions.

\section{Conclusions}

Our analysis of 3 key knowledge based occupations suggests the emergence of a new corporate pattern of professionalization, which departs in significant ways from the established paths pursued by traditional professions and may be more suitable for the realities of knowledge work and of the contemporary political economy. This approach contemplates a series of innovations with regards to closure, to membership propositions, client relationships, to the demarcation of jurisdictions and to the legitimization claims which are deployed. Such tendencies are increasingly relevant to established professions but most pronounced in the context of new knowledge based occupations such as the ones here described. A key feature is the increasing recognition of the importance of employing organizations as sites of professional formation and regulation. This has spawned a series of new policies and tactics, such as corporate membership schemes, which are designed to engage with corporate interests. Yet, this new corporate focus besides refurbishing traditional professional projects also raises the possibility of a progressive hollowing out of professional structures and institutions, as professional associations cede a growing number of their historical prerogatives to their corporate members (i.e. the accreditation of 
individuals) and downplay their regulatory functions in favour of their representative role and of the development of commercial services designed to attract new members.

\section{References}

Abel, R.L. (1988), The Legal Profession in England and Wales. New York: Blackwell.

Ackroyd, S. and D. Muzio (2007) 'The Reconstructed Professional Firm Explaining Change in English Legal Practices' Organization Studies, 48(5), pp 1-19.

Alvesson, M., A.W. Johansson. 2002. Professionalism and politics in management consultancy work. In T. Clark, R. Fincham, eds. Critical Consulting. Blackwell, Oxford, 228246.

Aronowitz, S. and Di Fazio, W. (1994) The jobless future: Sci-tech and the dogma of work. Minneapolis: University of Minnesota Press.

Beaverstock, J. V., Hall, S. and Faulconbridge, J. (2006) 'The internationalization of the contemporary European headhunting industry', In Harrington, J. W. and Daniels, P. W. (Eds.) Knowledge-Based Services: Internationalization and Regional Development. Cheltenham: Ashgate,, pp 125-152

Beaverstock, J. V., Hall, S. and Faulconbridge, J. (in press) Professionalization, legitimization and the creation of executive search markets in Europe. Journal of Economic Geography

Boltanski, L. and E. Chiapello (2005). The New Spirit of Capitalism. New York, NY, Verso.

Brint, S. G. (1994) In an Age of Experts: The Changing Role of Professionals in Politics and Public Life. Princeton: Princeton University Press.

Brock, D. M., Powell, M. J., \& Hinings, C. R. (1999). Restructuring the Professional Organization: Accounting, health care \& law. London: Routledge.

Burrage, M., K., Jaraush, and H., Siegrist (1990) 'An actor based framework for the study of professionalism' in Burrage, M. and Torstendahl, R. (eds.) The professions in theory and history. London: Rutledge.

Burris, B. (1993) Technocracy at work. New York: State University of New York Press.

Cooper, D., Lowe, A., Puxty, A., Robson, K., and Willmott, H. (1998) 'Regulating the UK Accountancy Profession: Episodes in the Relation between the Profession and the State'. Paper presented at the ESRC conference on Corporatism (London: Policy Studies Institute).

Dent, M. and Whitehead, S. (eds) Managing Professional Identities: Knowledge, performativity and the 'new' professional. London: Routledge.

Evetts, J. (1995) International Professional Associations: The New Context for Professional Projects. Work, Employment and Society. 9(4): 763-772.

Evetts, J. 2003. The Sociological Analysis of Professionalism: Occupational Change in the Modern World. International Sociology 18(2); 395 
Faulconbridge, J and Muzio, D. (2008) 'Organizational professionalism in global law firms'. Work, Employment and Society, 22(1): 7-25.

Faulconbridge J R (2007) "Exploring the role of professional associations in collective learning in London and New York's advertising and law professional-service-firm clusters" Environment and Planning A 39(4) 965 - 984

Faulconbridge, J., Hall, S. and Beaverstock J. V. (2008) 'New insights into the internationalization of producer services: Organizational strategies and spatial economies for global headhunting firms' Environment and Planning A 40(1): 210234.

Fincham, R. (2006) 'Knowledge work as occupational strategy: comparing IT and management consulting', New Technology, Work and Employment, 21(1): 16-28.

Fincham, R., Clark, T., Sturdy, A., and K. Handley (2007) 'Knowledge narrative sin management consultancy and professional services' in Muzio, D., S., Ackroyd and J.F., Chanlat (eds) New Directions in the Study of Expert Labour: Medicine, law and management consultancy. London: Palgrave

Glucker, J. and Armbruster, T. (2003) Bridging Uncertainty in Management Consulting: The Mechanisms of Trust and Networked Reputation, Organization Studies, 24 (2) 269297.

Grob, C. and A., Kieser (2006) 'Are consultants moving towards professionalization' in R Greenwood, R Suddaby and M McDougald (eds.) Research in the Sociology of Organizations: Professional firms Oxford: JAI Press

Hanlon, G. (1999) Lawyers, the State and the Market: Professionalism revisited. Basingstoke: Macmillan Business.

Hanlon, G. (1998) 'Professionalism as enterprise: Service class politics and the redefinition of professionalism'. Sociology 32 (1) 43-63

Hodgson, D. and Muzio, D. (2010) Prospects of Professionalism in Project Management in Morris, P. And Soderlund, J. (eds) The Oxford Handbook of Project Management. Oxford: Oxford University Press.

Jenn, N. (2005) Headhunters and How to Use Them (The Economist Publications, London)

Jones, S. (1989) The Headhunting Business (MacMillan, Basingstoke)

Johnson, T.J. (1972) Professions and power. London: Macmillan.

Kieser, S. 2002. Managers as marionettes? Using fashion theories to explain the success of consultancies', in M. Kipping, L. Engwall, eds. Management Consulting. Oxford University Press, Oxford, 167-183

Kipping, M., Kirkpatrick, I. and Muzio, D. (2006a) 'Overly controlled or out of control? Management consultants and the new corporate professionalism', in Craig, J. (ed.) Production Values: Futures for Professionalism, London: Demos.

Kipping, M. and Kirkpatrick, I. (2007) 'Professionalism without professions: the case of management consultants', in Muzio, D. Ackroyd, S. and Chanlat, F. (eds.) Redirections in the Study of Expert Labour: Law, medicine and management consultancy, London: Palgrave. 
Kirkpatrick, I, Muzio, D. and Ackroyd, S. (2011) 'Professions and Professionalism in Management Consulting' in T. Clark and M. Kipping (eds) The Oxford Handbook of Management Consulting Oxford: Oxford University Press

Kubr, M. 1996. Management Consulting. A Guide to the Profession, 3rd ed. Geneva : International Labour Office,.

Kyrö, P. 1995. The Management Consulting Industry Described by Using the Concept of 'Profession'. University of Helsinki, Research Bulletin 87, Helsinki.

Larson, M. S. (1977), The Rise of Professionalism: A sociological analysis. Berkeley: University of California Press.

Malhotra, N. and Morris, T. (2009) Heterogeneity in Professional Service Firms. Journal of Management Studies 46: 895 - 922

Marks, A. And Scholarios, D (2007) Revisiting technical workers: professional and organizational identities in the software industry. New Technology, Work and Organization 22(2): 98-117

McKenna, C. D. (2006) The World's Newest Profession: Management consultancy in the twentieth century. New York: Cambridge University Press.

Morris, P. W. G. (1997) The Management of Projects. London, Thomas Telford.

Morris, P. W. G., Crawford, L., Hodgson, D.E., Shepherd, M. M. and Thomas, J.. (2006). "Exploring the Role of Formal Bodies of Knowledge in Defining a Profession: The case of project management." International Journal of Project Management 24(8): 710-721.

Muzio, D., and S. Ackroyd (2005), 'On the consequences of defensive professionalism: The transformation of the legal labour process'. Journal of Law and Society 32(4): 615642

Muzio, D., S. Ackroyd, and J.F. Chanlat (eds) (2007) Redirections in the Study of Expert Labour: Established Professions and New Expert Occupations Basingstoke: Palgrave

Muzio, D., Kirkpatrick, I. and Kipping, M. (2010) Professionalism without professions: The case of management consultancy in the UK. CERIC working paper series, working paper N. 8.

Reed, M.I. (2007), Engineers of human souls, faceless technocrats or merchants of morality?: changing professional forms and identities in the face of the neo-liberal challenge in Ashly Pinnington, Rob Macklin and Tom Campbell (eds) Human Resource Management: Ethics and employment. Oxford: Oxford University Press

Reed, M.I. (1996), 'Expert power and control in late modernity: an empirical review and theoretical synthesis'. Organisation Studies (17)4: 573-597.

Suddaby, R., R., Greenwood and D., Cooper (2007) "Trans-national regulation of Professional Services: Governance dynamics of field level organizational change", 2007. Accounting, Organizations \& Society, 32: 333-362. 